ANNE IRFAN

a.irfan@,sussex.ac.uk

\title{
Educating Palestinian refugees: The Origins of UNRWA's unique schooling system
}

\begin{abstract}
This article examines the origins of UNRWA's schooling system for Palestinian refugees, probing how it began, who was behind it, and what the intended objectives were. Using archival evidence from numerous international welfare organizations and testimonies from refugees themselves, it argues that the bodies providing education and the people receiving it often had conflicting objectives that were highly politicized on both sides. Yet despite the comparatively greater power and resources of the UN, the refugees were able to exercise their limited agency in order to adapt the education system to their demands.
\end{abstract}

'[Schools] are an indispensable part of camp life for their morale value alone. As long as it is necessary to have refugee camps, there must be refugee schools in the camps."

Charlotte Johnson, League of Red Cross Societies, May 12, 1950

In May 1950, the Palestinian refugee crisis was about to enter its third year. The refugees' initial hopes that they would return to their homes in a matter of weeks had been utterly frustrated. Instead, just under a million Palestinians remained registered as refugees across the Middle East, with many taking shelter in improvised camps. ${ }^{2}$ Observing the potential longevity of the situation, relief organizations began to look at providing long-term services, particularly education. The opening quote from Charlotte Johnson signifies this developing thinking, yet Western aid agencies were not the first to look at refugees' schooling. Individual teachers among the refugee communities had already initiated efforts to provide schooling to Palestinian children in exile, setting up basic classes and even makeshift schools.

These efforts marked the beginning of what would eventually evolve into a fully-fledged education program for generations of Palestinian refugee children. When the UN Relief and Works Agency for Palestine Refugees (UNRWA) began operations in May 1950, it took over the running of these early schools in Syria, Lebanon, Jordan, the West Bank and Gaza. Momentously, UNRWA introduced free education for registered Palestinian refugee children across the geographical fields in which it worked. Within a decade, education had become the Agency's largest program in terms of both budget and personnel. ${ }^{3}$ A unique situation thus developed whereby an international organization administered a specially-devised schooling system 
for one national group. As this became an essential element of Palestinian exile, Charlotte Johnson's comment in May 1950 turned out to be not only an accurate description of the situation in the camps at the time, but prescient of what was to come.

This article focuses on the early years of Palestinian exile, to examine how UNRWA's unique education system came to be established. It identifies the main actors involved in creating schooling for Palestinian refugee children, and explores their various motives. In probing these questions, the article assesses the extent to which UNRWA's unique education system aligns in practice with what was originally intended. Evidence is taken from the early records of the organizations responsible for developing the first schools in Palestinian camps: most notably UNRWA, but also the Red Cross, the American Friends Service Committee (AFSC), and the UN Educational, Scientific and Cultural Organization (UNESCO). The accounts of individual refugees and other observers in the camps supplement this content to show how the education system functioned in practice.

Three core arguments are drawn from this evidence. Firstly, this article shows that the refugees themselves drove early education efforts in the camps, and then continued to play an active role in shaping the UNRWA programme. Secondly, it is argued that the refugees and UNRWA had opposing and conflicting motives when it came to camp education, with the former driven by nationalist concerns and the latter by global politics. On this basis, the third argument follows that resulting confrontations over camp schooling made UNRWA's education programme emblematic of the inherent tension in its set-up, as well as its complex relationship with the refugees.

In addressing this topic, this article takes a unique approach to an important subject. There is a general scholarly consensus that UNRWA's provision of universal free education had a transformative impact on Palestinian society and national politics among the shatat (diaspora). ${ }^{4}$ Rashid Khalidi, Michael Dumper and Jalal Al Husseini have all written about its positive and progressive socio-economic impact, ${ }^{56}$ while David Forsythe and Julie Peteet have emphasized its influence on Palestinian national identity. ${ }^{7}$ However, these analyses tend to be retrospective, assessing the effects of the education program. This article takes a different approach by examining its origins, a subject that has been largely overlooked.

This oversight is particularly glaring because of the topic's importance; it is only by studying the programme's origins that we can gain a comprehensive understanding of its set-up and purpose. As the 
aforementioned scholars have noted, the UNRWA education programme has been a key feature of Palestinian exile, helping shape the political, social, culture and economic conditions of the refugee camps. Generations of Palestinians who came through the UNRWA education system went on to become key figures in shaping the politics of much of the Middle East. Understanding the ethos behind the system is thus crucial to understanding this history.

The origins of the UNRWA education program are further emblematic of the complexity and contradictions of the Palestinian refugee crisis itself. This early period saw the emergence and embedding of features that would characterize the Palestinian refugee situation over subsequent decades: the active agency of the refugees themselves; their unique treatment in the framework of the UN; and the inherent politicization of humanitarianism. More generally, the UNRWA schooling system constitutes a valuable case study of an internationalized response to a regional refugee crisis, the shifts from immediate relief to medium-term development, and the use of education as part of a wider humanitarian project.

This article is organized into three sections. Firstly, it examines early efforts to provide education in the camps immediately after the Nakba*, focusing on the role played by the refugees themselves. Building on this context, the second section then addresses the beginning of UNRWA's work, investigating whether the onset of its large-scale education program showed more continuity or change with what had gone before. The second section will also establish how the Agency's objectives were diametrically opposed to those of the refugees, creating a fundamental and lasting tension in their relationship. Finally, the third section examines in detail the longterm significance of this early period, probing what it signifies about the intersection between politics and humanitarian projects in the mid-twentieth century.

\section{Early Education Efforts, 1948-50}

Although UNRWA became inextricably linked with Palestinian refugee education, it was not responsible for the first camp schools. In fact, the earliest moves to provide schooling for Palestinian children in exile came not from any organization, but from individuals within the community. ${ }^{8}$ Many of the first classes were set up by refugees who had been teachers in Palestine and were determined that the Nakba* would not put a stop to children's education. ${ }^{9}$ As early as 1948, makeshift classes were being

\footnotetext{
*'The term 'Nakba' literally means 'catastrophe', and is used to refer to the Palestinians' national dispossession, expulsion and dispersal in 1948.
} 
conducted in tents or outside in the open-air [see Figure 1]. ${ }^{10}$ At the beginning of 1950, the only refugee school operating in Jordan was one that had been set up by refugee teachers in Al Karama camp, without any external assistance. ${ }^{11}$ This exemplifies the refugee agency that has characterized Palestinian exile.

It was also in keeping with the Palestinian refugees' widespread demand for education for their children. Many saw education as a way out of the poverty and deprivation they were now facing, and accordingly seized any opportunity to educate their children. ${ }^{12}$ Maya Rosenfeld and Yezid Sayigh point out that the camp refugees were overwhelmingly of peasant origin; having lost the land that had defined them and been their main currency for generations, they now looked to education as the key to improving their prospects. ${ }^{13}$ Moreover, many were uneducated themselves and felt that they had lost their country in 1948 because of ignorance. ${ }^{14}$ They therefore embraced education was not only as the key to better prospects, but also a tool for reclaiming Palestine.

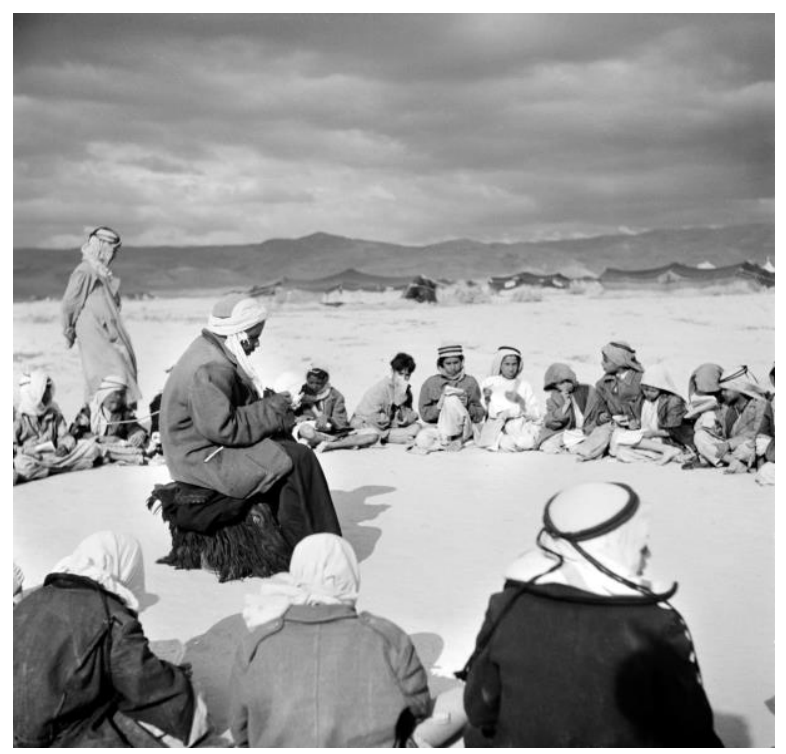

Figure 1: An early open-air class in Jericho, West Bank in 1948. Source: UNRWA.

As a result, Palestinian refugees throughout the region tended to be highly responsive to any opportunity to educate their children. ${ }^{15}$ As the months in exile rolled on, such opportunities came not only from refugee teachers but also from the range of organizations providing services prior to UNRWA's arrival on the scene in May 1950. Chief among these were the UN Disaster Relief Project (UNDRP), UN Relief for Palestine Refugees (UNRPR), the International Committee of the Red Cross (ICRC), the League of Red Cross Societies (LORCS), and the American Friends Service Committee (AFSC). The latter established camp schools in Gaza from March 1949, while the Red Cross worked in the other fields. ${ }^{16}$ Ecumenical organizations also played a role; in addition to the work of the Pontifical 
Mission for Palestine, the Congregational Christian Service Committee, and the Church World Service, ${ }^{17}$ an individual Armenian Catholic priest was responsible for starting the El Buss camp school in Lebanon in 1949. ${ }^{18}$

However, these piecemeal attempts were insufficient to meet the refugees' ardent demands for education services. In 1950, the Red Cross reported that it had received numerous requests and petitions to open more schools and expand the existing ones. Charlotte Johnson and Peter Malak remarked on sad scenes of non-enrolled children standing outside schools and looking longingly at their counterparts inside. In what would become a familiar refrain for UNRWA over the decades, the Red Cross added that it had to decline these requests due to insufficient funding. ${ }^{19}$ The following year, a report from the Anglican Church in Jerusalem noted 'ever-increasing demand among refugee parents for education for their children', with insufficient schools to meet it. ${ }^{20}$ The demand for a more comprehensive system was palpable. UNRWA arrived at just the right time.

\section{The role of UNESCO}

On the surface, the aforementioned multiplicity of organizations operating in the camps at this time might suggest a variance in activities and objectives. In reality, their operations were often fairly standardized. Moreover, many of the schooling norms established at this time were continued by UNRWA, for the simple reason that these organizations were largely funded by and answerable to the same players, usually via the UN. The latter not only oversaw UNDRP, UNRPR and later UNRWA, but also commissioned the AFSC's work in Gaza. From November 1948, UNRPR functioned as an umbrella body, overseeing the activities of the various NGOs. ${ }^{21}$ As a result, the provision of relief services was shaped by the same concerns driving the UN at the time. As the latter was dominated by the Western powers and particularly the US, its policy towards the Palestinian refugees in the late 1940s was consequently shaped by political sensitivities around the right of return and the new Israeli state. ${ }^{22}$ This was not lost on the Palestinian refugees, and would become a key factor in their difficult relationship with UN agencies.

The continuity provided by the ongoing role of the UN, and indirectly the US, meant that in many ways, the schooling projects of 1948-50 laid the foundations for what would become UNRWA's flagship education program. As such, this early period is not mere background, but explains how and why UNRWA's education program developed in the way that it did. The events of 1948-50 illustrate the UN's inextricable entanglement with the plight of the Palestinian refugees, and the latter's lasting connection to the international scene. Moreover, the nature of the set-up meant that 
politics was a constant, if unofficial feature of humanitarian projects with the Palestinian refugees - a feature that would characterize UNRWA's work in ensuing decades. It is in this context that the origins and purpose of the early refugee schools is best understood.

One UN body in particular is especially important for understanding the lasting significance of this period for UNRWA's education program: UNESCO. UNESCO's role in educating Palestinian refugees has been largely under-studied and is insufficiently considered in much of the relevant literature. While UNRWA is responsible for serving Palestinian refugees, it has delivered its education program in partnership with UNESCO from the beginning. ${ }^{23}$ The two bodies issued joint Annual Education Reports, and went on to establish the UNRWA-UNESCO Institute of Education in 1964. ${ }^{24}$ Moreover, UNESCO's involvement in providing education for Palestinian refugees preceded that of UNRWA - a significant factor in explaining the consistency between the late 1940s and subsequent years.

UNESCO first became involved in refugee schooling in response to the aforementioned demand from the refugees themselves. It provided lowkey support to the refugees' school in Al Karama, and then began coordinating bigger plans with NGOs on the ground. In May 1949, UNESCO forged an agreement with the LORCS over a schooling program to be used in schools for Palestinian refugees in Lebanon, Syria and Jordan. The program was initially intended to last four months, with measures put in place to enable its continuation if necessary. ${ }^{25}$ This foreshadowed the nature of UNESCO's later involvement, when it would work with UNRWA on developing curricula for the Palestinian camps. ${ }^{26}$

Many of the decisions taken by the LORCS and UNESCO would have lasting consequences for the education program later implemented by UNRWA across the five geographical fields in which it worked: Syria, Lebanon, Jordan, the West Bank and Gaza. Most crucially, while the Red Cross' early program had tended to use the former syllabus of Mandate Palestine, it now approved the move to use host state textbooks and curricula. ${ }^{27}$ This would become a hallmark of schooling for Palestinian refugees across the five fields. ${ }^{28}$

Other precedents came in the international organizations' relations with Palestinian teachers. In employing Palestinian refugees to teach in camp schools, UNESCO established another feature that would become a key feature of the UNRWA system. In 1953, UNESCO reported that the 1,527 teaching staff in camp schools were 'all Palestinian refugees'. ${ }^{29}$ Their employment in this guise was consistent with their earlier role in initiating the first camp schools after the Nakba. At the same time, this set-up also 
ushered in the multi-layered and often difficult relationship between Palestinian refugee teachers and the international organizations employing them. From early on the former complained about their insufficient pay and requested better conditions. The LORCS supported them in this, stating in overtures to the UN that the teachers' allowance was 'unsound, unjust and unsafe. ${ }^{30}$ In future decades, UNRWA would be faced repeatedly with the same grievances from Palestinian teachers.

Most importantly, UNESCO's interventions at this time provided a harbinger of how UNRWA would later depict its schooling program when seeking financial support on the world stage. In 1949, UNESCO issued appeals to governments around the world, requesting funding for its efforts to provide schooling for refugee children. These appeals were couched in humanitarian terms about the well-being, future prospects, and 'right to learn' of 200,000 refugee children. ${ }^{31}$ UNESCO reported that the resulting donations led to the establishment of 31 emergency schools in the camps. ${ }^{32}$ Similarly, UNRWA would later continually highlight the humanitarian impact of its education program, selling it as a multi-faceted welfare project with widespread socio-economic benefits. At the same time, the Agency often gently alluded to its positive contribution to political stability in the region. ${ }^{33}$

\section{The establishment of UNRWA}

When the newly-created UNRWA began operations, then, it was neither the first organization to provide services to Palestinian refugees, nor even the first UN agency to do so. Instead, UNRWA's distinguishing feature was that it was constructed as a comprehensive relief system after the more piecemeal efforts of UNRPR, the AFSC and the LORCS. Indeed, its creation was justified by way of this distinction. In November 1948, UNRPR's work had been premised on the understanding that the political causes of the refugee crisis would be resolved imminently. ${ }^{34}$ As it became increasingly clear that this was not to be, the UN sought to establish a more comprehensive arrangement. In December 1949, the UN General Assembly (UNGA) adopted Resolution 302(IV) to create an agency with a mandate to carry out 'direct relief and works programs [for Palestine refugees]... in collaboration with local governments [in the five fields].' ${ }^{35}$ This was UNRWA.

In keeping with the objective that it should be a comprehensive system, UNRWA took over the running of all Palestinian refugee schools when it began operations in May 1950. At the beginning of the 1950/51 school year, the Agency was running seventy-four schools across its five fields, with 700 teachers and 35,700 pupils. ${ }^{36}$ The program expanded 
quickly; by late 1954, UNRWA was responsible for 242 elementary schools, and 154,735 students, including those it subsidized in government and private schools. ${ }^{37}$ UNRWA would later cite the large size and comprehensive nature of its education program as positive attributes. Defending the Agency in a 1973 article, the Public Information Officer George Dickerson wrote proudly that it was 'comparable in size, scope and complexity with a national education system?. ${ }^{38}$

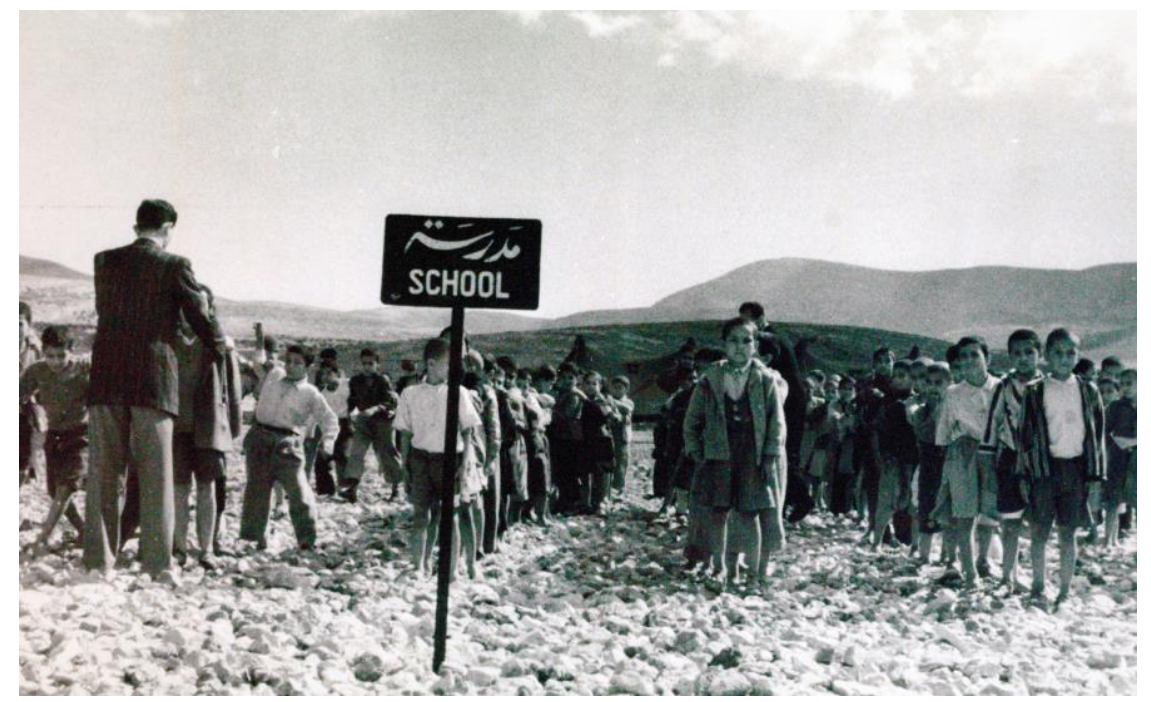

Figure 2: The first school in Jalazone refugee camp, West Bank, 1950. Source: UNRWA.

The continuing involvement of the UN, not least via UNESCO, ensured that the transition to the UNRWA system was marked by more continuity than change. However, its impact on Palestinian society was still considerable. In providing all registered refugee children with free access to education, the program was socially and politically transformative. From the mid-1950s, education constituted the Agency's largest program in terms of budget and staffing - an importance it has retained to this day.

By comparison, in 1940s Mandate Palestine only 3 in 10 Palestinians had attended school. ${ }^{39}$ Now, near-universal literacy among the refugees was achieved within a generation. ${ }^{40}$ UNRWA also proudly cited its positive effects for gender equality. ${ }^{41}$ The provision of free education to all children meant that families no longer saved to educate their sons while keeping their daughters at home - as had been the case in the initial period of exile, when schooling places were more limited. ${ }^{42}$ As a result, education rates among Palestinian girls increased hugely in both relative and absolute terms in the 1950s and 1960 s. ${ }^{43}$ Of course, full equality was not achieved, and UNRWA continued to reinforce conventional gendered ideas with its separate vocational subjects for boys and girls [see Figure 3]. ${ }^{44}$ Nevertheless, the education program had an important impact in raising female literacy and increasing opportunities for Palestinian refugee women. 


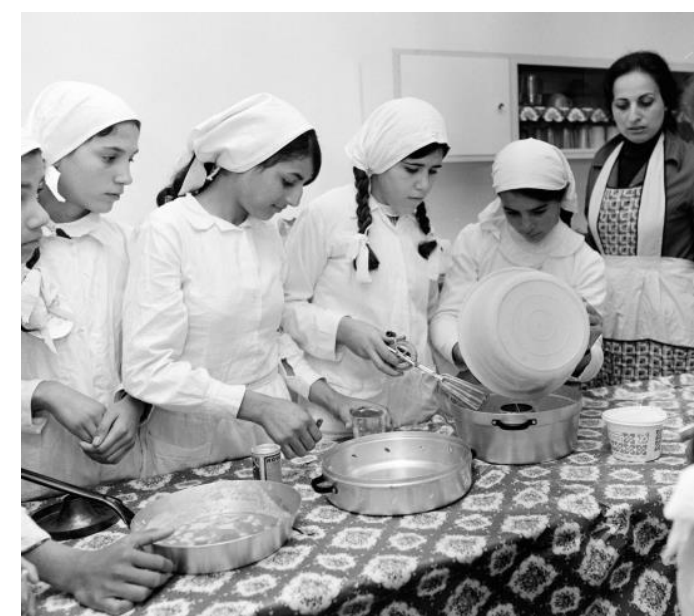

Figure 3: Palestinian girls learn cookery at the New Amman School in Jordan, 1973. Source: UNRWA.

\section{UNRWA's motives: Refugee 'reintegration'}

Like UNESCO, UNRWA largely characterized the motives behind its education policy as humanitarian, progressive and apolitical. In a 1952 memo, the Agency's Chief of Education J. Robbins stated:

Education alone among the relief services offers the possibility of developing the resources remaining in the possession of the Palestinian Community [sic]. It is able to add to their capital equipment, to prepare them for re-establishment without prejudging the answer to the questions of 'when' and 'where'. ${ }^{45}$

This internal memo, sent to the UNRWA Executive Office to appeal for more investment in education, is constructed in highly revealing language. Robbins, evidently aware of the imperatives of the Agency's apolitical mandate, underlines that the program has no bearing on what he calls the 'highly controversial questions' around how the Palestine refugees' plight should be resolved. At the same time he emphasizes the benefits that education brings to the Palestinians in exile, and its uniqueness in comparison to the other services provided by UNRWA. In speaking about the long-term benefits of education for Palestinian refugees, Robbins invoked the same ideas behind UNESCO's 1949 appeals for funding. ${ }^{46}$

This messaging was in keeping with UNRWA's presentation of itself as a non-political organization that was solely concerned with welfare and detached from political engagement. ${ }^{47}$ From its creation, UNRWA management were keen to emphasize that the Agency had no political mandate and was not involved in pursuing solutions to the refugee crisis. At most, official communications from the Agency acknowledged the political nature of the Palestinian refugee issue, while clarifying that its own work was limited to the provision of services. ${ }^{48}$ Successive Directors and Commissioner-Generals stated in their annual reports that the Agency went 
no further than endorsing the call for the refugees' return in UNGA Resolution $194 .^{49}$

Behind the scenes, the line between politics and service provision was rather more blurred. Notwithstanding UNGA Resolution 194, by the early 1950 s the UN was increasingly moving away from the notion of repatriation, which the new Israeli government had firmly rejected. ${ }^{50}$ Instead, the UN was looking to the refugees' so-called 'reintegration' into the host countries as an alternative solution. ${ }^{51}$ On the world stage, both the US and the UK looked unfavourably on the idea of return and publicly voiced support for the refugees' resettlement in Arab states. ${ }^{52}$ This was in keeping with the era's shifting priority in refugee policy from repatriation to non-refoulement, with a resulting emphasis on resettlement as a durable solution. ${ }^{53}$

Contrary to its claims in official communications, UNRWA' status as a UN body meant that it did not remain detached from this. In fact the Western powers that dominated the UN saw UNRWA as a key tool for achieving the objective of 'reintegration'. Internally, the UK Foreign Office even stated that the Agency had in fact been created as a means to implement resettlement. ${ }^{54}$ Nor was this entirely secret; in 1952 the UNGA, to which UNRWA reported, officially endorsed the resettlement policy in Resolution 513. At the same time, it authorized a $\$ 200$ million 'Reintegration Fund' to enable the Agency to accomplish the full integration of the Palestine refugees into the host countries over a three-year period. ${ }^{55}$

Thus despite the official insistence about its apolitical mandate, ${ }^{56}$ UNRWA was working not merely to provide relief but to actually implement a political solution to the Palestine refugee crisis. Indeed, the documents further reveal that behind the scenes, UNRWA management were relatively open about this objective. In a private meeting with UNESCO in 1952, Director Blandford admitted that he was 'doing his best to get the Arab governments to agree to the resettlement of the refugees' ${ }^{.57}$

The education program was central to this objective. The UNESCO representative Dr Matta Akrawi reported in 1952 that the UNRWA Director would only allow educational budgetary increases for activities closely linked to reintegration. Akrawi added that when pushed, the Director revealed that this restriction came from the US State Department. ${ }^{58}$ Akrawi's report does not indicate which activities came into this category, but it is particularly significant in view of the debates that have raged for decades over UNRWA's insistence on using host state curricula in its schools. Accordingly, the latter is worth considering briefly here. 
From the beginning, the Agency took the decision to continue using host state curricula - as its predecessors had done in refugee schools rather than developing a uniquely Palestinian one. It accordingly organized its schooling system in consultation with the host governments. ${ }^{59}$ This was explained on the grounds that it enabled the refugees to compete in local job markets - UNRWA management continually and publicly cited the 'overwhelming advantage' this proffered in permitting Palestinian refugee children to participate in secondary and higher education in the host states. ${ }^{60}$ As a lesser point, they also argued that the policy enabled Palestinian refugee children to maintain their connection with Arab culture. ${ }^{61}$ However, the decision did not go unquestioned. Critics condemned it as a move designed to facilitate the refugees' resettlement in the host states and eradicate any distinctive Palestinian identity. In the light of the Agency's unofficial reintegration objective, this does not seem an unreasonable characterization.

Palestinian scholar Ibrahim Abu Lughod provided one of the most forceful critiques of the policy. In 1973, he wrote that the use of Arab state curricula to educate Palestinian children was depriving them of any in-depth knowledge of their history, particularly the struggle against the Zionist movement. Instead, it was presenting the liberation of Palestine as an Arab problem, with the effect of 'weaken[ing] Palestinianism'. In more strategic terms, he further argued that the curricula and teaching methodologies of stable societies were inappropriate for educating an exiled community that was seeking national liberation. ${ }^{6}$

Unsurprisingly, UNRWA management themselves rejected these charges. Writing in direct response to Abu Lughod's criticisms, UNRWA Public Information Officer George Dickerson contended in 1974 that the Agency's education program contributed directly to 'the preservation of the Palestine refugees' identity with the Palestine culture [sic].' He attributed this to the existence of a predominantly Palestinian student and teaching body in UNRWA schools. He also pointed out that an autonomous Palestinian-run education program would be impossible in the occupied West Bank and Gaza. ${ }^{63}$ More generally, UNRWA management were keen to highlight that the Arab host states themselves favoured the curriculum policy. ${ }^{64}$ Indeed, in 1968, the Conference of Arab Ministers of Education had complained about reports that UNRWA has ceased applying host state curricula in its schools. ${ }^{65}$ From this perspective, then, the Agency was simply complying with the wishes of the governments hosting its work.

\section{Lasting Repercussions: The politics of UNRWA's education program}

Needless to say, UNRWA failed decisively in its attempts to inculcate the refugees' 'reintegration' into the Arab host states. Despite years and 
eventually decades of being educated in the systems of the host countries, successive generations of refugees retained a decisive and significant sense of themselves as Palestinian - even in Jordan, where many held citizenship. ${ }^{66}$ Two decades after beginning its operations, UNRWA publicly acknowledged 'the enhanced political consciousness of the Palestine refugee community'. ${ }^{67}$ The reasons for this unintended outcome are worth considering in some detail.

The failure of reintegration was due in no small part to the actions of the refugees themselves. They were fiercely opposed to any 'solution' to their plight besides return to Palestine. Suspecting that UNRWA's real purpose was to facilitate their resettlement outside Palestine, refugee organizations frequently reiterated their demands to return home, in accordance with UNGA Resolution $194 .{ }^{68}$ Accordingly, they largely rejected any programs tainted with the objective of resettlement. This was most true of the UNRWA 'Works' schemes in the 1950s, which were intended to facilitate the refugees' economic integration in the host states by way of local employment. Groups of refugees rejected the schemes as 'imperialist', ${ }^{69}$ and overwhelming numbers boycotted them. Of the 878,000 refugees registered with the Agency in the early 1950s, the largest number ever employed under its Works Program was 12,000, and in less than a year this had reportedly dwindled to $812 . .^{70}$

Instead of the Works schemes, the refugees were determined to secure education for their children. Yezid Sayigh has described their keenness on this front as an 'obsessive new striving', such was its intensity. ${ }^{71}$ Indeed, while the refugees were overwhelmingly averse to the Works schemes, they responded to the prospect of education with great enthusiasm, shared by everyone from teachers and administrators to the students themselves and their parents [see Figures 4 and 5]. ${ }^{72}$ Their only criticism of UNRWA's early schooling program was that it did not cover all years. 


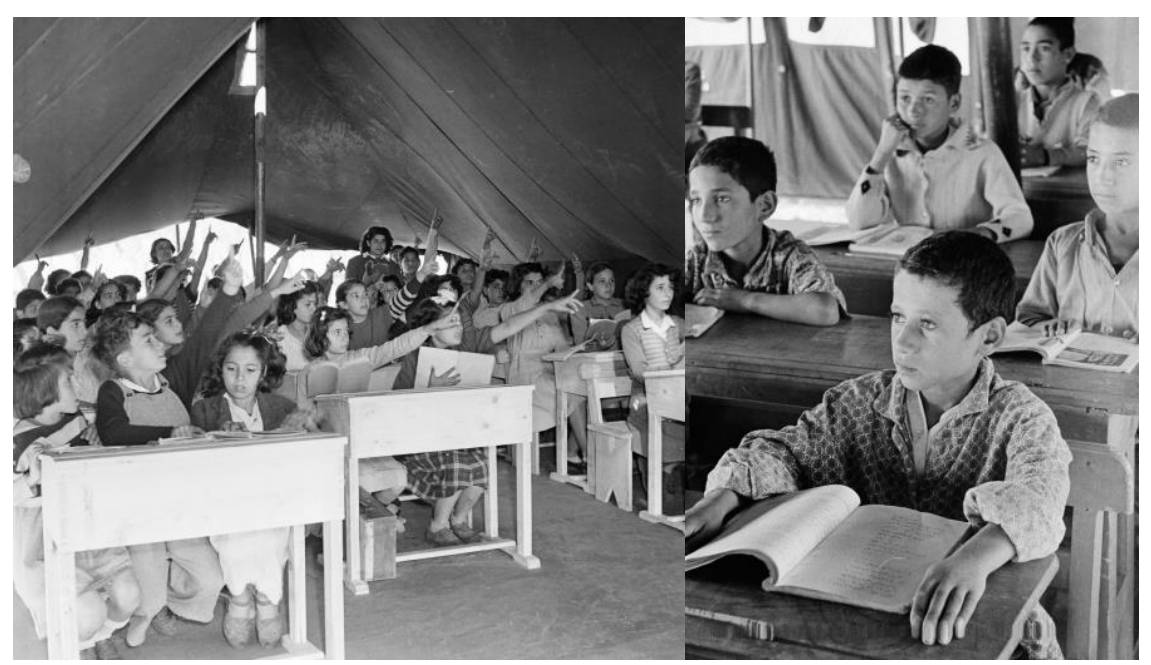

Figure 4 [left]: Palestinian refugee girls participate in class at Mar Elias camp in Lebanon, 1953. Figure 5 [right]: Palestinian refugee boys concentrate in class at Souf camp in Jordan, 1950. Both sourced from UNRWA.

However, this is not to say that the refugees were aligned with UNRWA in seeing education as a tool for their 'reintegration' in the host states. In fact, their motives and rationale were entirely at odds with those of the Agency. There was a widespread feeling among Palestinians in the camps that they had lost their country in 1948 precisely because of their comparative lack of education vis-à-vis the yishuv Jewish community in Mandate Palestine]. ${ }^{73}$ After the Nakba, many refugees noted the disadvantage at which this had placed them, which fuelled their desire to ensure that the next generation was educated. ${ }^{74}$ The political significance of education in this sense rendered it the polar opposite of the hated 'reintegration' schemes in the eyes of the refugees. They saw it instead as a tool to facilitate their return to Palestine.

The refugees also desired education for more abstract reasons. As Yezid Sayigh notes, it was not only about gaining material security, but also identity and dignity. ${ }^{75}$ The latter was particularly important, as many refugees felt that relying on UNRWA services while living in camps was humiliating ${ }^{76}$ - Fawaz Turki, who grew up in Burj al-Barajneh camp in Lebanon, described the Agency as "that ubiquitous symbol of shame in our lives." 77 Like fellow refugee Leila Khaled, he recalls the degradation that his parents felt over having to collect their rations from the UNRWA provisions bureau. ${ }^{78}$ As the Agency's aid supplies were seen to signify their national defeat, the refugees generally sought to draw whatever benefits they could from it while keeping up their demands for real justice in the form of return. Education lay at the core of this approach.

The refugees' demands bore fruit on numerous fronts. Firstly, they were substantial enough to be noted at a high level - in 1952, a UN Working Group spoke of the great pressure coming from Palestinian refugees for 
adequate education. ${ }^{79}$ At the same time, their aversion to the Works scheme meant that the latter failed to take off, and UNRWA had to dispense with it by 1957.80 From the mid-1950s, the Agency was focusing on education as an alternative approach. ${ }^{81}$ Schools were now declared the new priority. ${ }^{82}$ Although the Agency had been responsible for camp schools since it began operations in 1950, it had run its education program on a small scale for the first half of the decade. ${ }^{83}$ That now changed; the education program, developed in partnership with UNESCO, expanded significantly. ${ }^{84}$ The number of UNRWA schools increased from 61 in 1950 to 386 in $1958 .{ }^{85} \mathrm{In}$ subsequent years, UNRWA's school program developed into a modern-style education system, operating at elementary and middle school level and also providing university scholarships to exceptional students.

Of course, while acquiescing to the refugees' demands for more largescale education, UNRWA did not accept the premise that this would be a tool to facilitate their return. On the contrary, whatever the ostensible justification for using host state curricula, UNRWA's insistence on the latter indicated its reluctance to push for the refugees' repatriation. However, there was a postscript. Just as the Palestinians had succeeded in spurning the Agency's "Works" schemes in the early 1950s, in subsequent decades they succeeded in lobbying UNRWA to compromise on its use of host state curricula. ${ }^{86}$ From the late 1960s, the Agency capitulated to pressure to incorporate Palestinian history and geography into its schools.$^{87}$ The use of UNRWA schools to promote awareness of the Palestinian national heritage in this way was the final and most explicit sign that attempts to 'reintegrate' the refugees by way of education had failed decisively. Instead, the Palestinian national identity endured in exile.

The refugees thus effectively turned the original purpose of the schooling program on its head, ensuring that rather than facilitating their 'reintegration', it instead bolstered Palestinian national identity. ${ }^{88}$ As Rosemary Sayigh argues, a similar phenomenon occurred with the camps themselves, which were intended to contain the Palestinian refugees and thus limit their organizational capacity, but instead ended up acting as hubs for the nationalist movement in exile. ${ }^{89}$ These contrary outcomes were the result of the complexity and contradictions surrounding the origins of policies for the Palestinians in exile. As noted at the outset of this article, the first camp schools were established not by UNRWA or the UN at all, but by the refugees themselves, who went on to populate the UNRWA schools as teachers and students. As their objectives were at odds with those of the Agency, they exerted their limited agency to ensure that the latter did not dominate but were continually compelled to compromise.

\section{Conclusion}


The early development of the education program for Palestinian refugees denotes several significant points about their history. Most importantly, the refugees' victories in first securing more education, and then modifying the system to include Palestinian-specific subjects, are highly significant. These victories demonstrate the refugees' ongoing propensity to exercise whatever agency they had - however limited - in order to sway events in their favour. As the example of their early education shows, the Palestinian refugees were not ignorant and passive recipients of international aid, but active agents who organized themselves to make demands and have their voices heard.

When considering the refugees' active role, it is particularly important to note that UNRWA's education program, which has become a defining feature of the Agency's work, was built on foundations first established by Palestinian refugees themselves. As noted in the first section of this article, it was individual refugees who took the first steps to create classes and makeshift schools for Palestinian children in exile. Contrary to what is often assumed, UNRWA did not introduce education into a setting from which it was previously entirely absent.

Furthermore, the enduring role of the UN and particularly UNESCO ensured that UNRWA's arrival on the scene was marked by more continuity than major change. The Agency adopted many of the policies adopted by previous organizations, albeit on a larger and more comprehensive scale. The most significant differences are thus found not between UNRWA and its predecessors, but between the organizations' collective approach to education and the demands of the refugee students and teachers. As the UNESCO documents show, these differences and the resulting tensions preceded UNRWA's creation; in many ways UNRWA picked up a pattern that had already been established.

Yet the nature of these tensions is still highly revealing about UNRWA itself. Differences with the refugees over whether education would facilitate resettlement or repatriation show that UNRWA was demonstrably involved in the politics of their plight - in spite of its claims to be a purely humanitarian organization detached from politics. Moreover, the Agency's adaptation of its services in response to the refugees' demands is indicative of the flexibility that it needed to show when navigating its relationship with the people to whom it provided services.

This article has addressed how UNRWA's education program originally came to be established, what its objectives were, and who was behind it. In exploring these questions, it has also demonstrated broader points about the Palestinian experience of exile, including the refugees' 
activism and the ongoing politicization of the international welfare services provided to them. UNRWA's free and comprehensive education program for Palestinian refugees has long been cited as a key aspect of their exile and as one of the Agency's most beneficial services. This article has shown that its significance goes even further than this, and that its origins were emblematic of many of the wider themes of Palestinian refugee history.

\footnotetext{
${ }^{1}$ Charlotte Johnson, Red Cross Chief Social Welfare Advisor, Report on Schools Directed by the League of Red Cross Societies in Lebanon, Syria \& Jordan, May 12, 1950, ED 157/366, Public Records Office [PRO], UK.

${ }^{2}$ UNCCP, Summary Record of a Meeting between the Conciliation Commission and Representatives of Relief Organizations in Geneva, June 7, 1949, A/AC.25/SR/LM/17, accessed December 19, 2016, https://unispal.un.org/DPA/DPR/unispal.nsf/0/852F50FC79431DA985257513006DB8B5

${ }^{3}$ Riccardo Bocco, "UNRWA and the Palestinian refugees: A History within History," Refugee Survey Quarterly 28:2-3 (2010): 232.

${ }^{4}$ See for example: Rashid Khalidi, Palestinian Identity: The Construction of Modern National Consciousness (New York: Columbia University Press, 1997), 194; Jalal Al Husseini, "UNRWA and the Palestinian nationbuilding Process," Journal of Palestine Studies 29:2 (Winter 2000): 51-64; Milton Viorst UNRWA and Peace in the Middle East (Washington DC: Middle East Institute, 1984); Julie Peteet Landscape of Hope and Despair: Palestinian Refugee Camps (Philadelphia: University of Pennsylvania Press, 2005); Maya Rosenfeld, "From Emergency Relief Assistance to Human Development and Back: UNRWA and the Palestinian Refugees, 1950-2009," Refugee Survey Quarterly 28:2-3 (2010): 286-317; Ghassan Shabaneh, "Education and Identity: The Role of UNRWA's Education Programmes in the Reconstruction of Palestinian Nationalism', Journal of Refugee Studies 25:4 (2012): 491-513.

${ }^{5}$ Michael Dumper, "Introduction," in Palestinian Refugee Repatriation: Global Perspectives, ed. Michael Dumper (Oxfordshire: Routledge, 2006), 4.

${ }^{6}$ Khalidi, Palestinian Identity, 194; Jalal Al Husseini, "UNRWA and the Refugees: A Difficult but Lasting Marriage," Journal of Palestine Studies 40:1 (Autumn 2010): 14.

${ }^{7}$ David Forsythe, "The Palestine Question: Dealing with a Long-Term Refugee Situation," Annals of the American Academy of Political and Social Science 467 (May 1983): 93; Peteet, Landscape of Hope and Despair, 125128; Yezid Sayigh, Armed Struggle and the Search for State: The Palestinian National Movement 1949-93 (Oxford: Oxford University Press, 1997), 53.

${ }^{8}$ UNRWA later acknowledged this in Palestine Refugees Today 126, May 1990, RSC.

9 UNESCO, “The Education of Palestine Arab Refugees," UNESCO/ED/31, August 31, 1953, accessed January 20, 2017, http://unesdoc.unesco.org/images/0012/001261/126137EB.pdf

10 "Palestinian refugee boys in tent school in Khan Younis, Gaza," UNESCO, accessed January 20, 2017, http://www.unesco-ci.org/photos/showphoto.php/photo/4743/title/palestine-refugee-boys-in-tentschool-in-khan-younis-2c-gaza-/cat/all

${ }^{11}$ Charlotte Johnson, Report on Schools, PRO.

${ }^{12}$ Fawaz Turki, The Disinherited: Journal of a Palestinian Exile (New York: Monthly Review Press, 1972), 39-

41. Abdel Bari Atwan, $A$ Country of Words: $A$ Palestinian Journey from the Refugee Camp to the Front Page (London: Saqi, 2008), 28. Salman Abu Sitta, Mapping My Return: A Palestinian Memoir (New York: The American University of Cairo Press, 2016), 101.

${ }^{13}$ Rosenfeld, "From Emergency Relief Assistance to Human Development and Back," 312. Y. Sayigh, Armed Struggle and the Search for State, 47.

${ }^{14}$ Rosemary Sayigh, Too Many Enemies: The Palestinian Experience in Lebanon (London: Zed Books, 1994), 5455.

15 Turki, The Disinherited, 39-41.

${ }^{16}$ Benjamin Schiff, Refugees Unto the Third Generation: UN Aid to Palestinians (Syracuse: Syracuse University Press, 1995), 27.

${ }^{17}$ Charlotte Johnson, Report on Schools, PRO.

${ }^{18}$ Letter from R.W. Highwood, British Legation Representative in Lebanon, to HM Minister Beirut, July 10, 1949, FO 371/75328, PRO.

${ }^{19}$ Charlotte Johnson, Report on Schools, PRO.

${ }^{20}$ Report: Arab Refugees in the Jerusalem Area including Bethany, 1951, GB165-0161, Jerusalem and East Mission Collection, File 2, Box 73, Middle East Centre Archive [MECA], St Antony's College, Oxford, UK.

${ }^{21}$ Ilana Feldman, "Difficult Distinctions: Refugee Law, Humanitarian Practice, and Political Identification in Gaza,” Cultural Anthropology 22:1 (2007): 134.
} 
${ }^{22}$ Irene Gendzier, Dying to Forget: Oil, Power, Palestine, and the Foundations of US Policy in the Middle East (New York: Columbia University Press, 2016), 231-239, 254-262

${ }^{23}$ Schiff, Refugees Unto the Third Generation, 28.

${ }^{24}$ Agreement between UNESCO and UNRWA and the Government of Switzerland concerning the UNRWA/UNESCO Institute of Education, November 1964, File RE230(L-1) II, Box RE21, UNRWA Headquarters' Archive [UHA], Amman, Jordan. For more on the Institute's activities see: Letter from A. Reddaway, Acting UNRWA Commissioner-General, to the Lebanese Minister of Education, February 15, 1965, File RE230(L1) II, Box RE21; UNRWA/UNESCO Institute of Education, “A Brief Note on the Institute's Extension Services," File RE230(L-1) VI, Box RE21, both at UHA.

${ }^{25}$ Charlotte Johnson, Report on Schools, PRO.

${ }^{26}$ Shabaneh, "Education and Identity," 507.

${ }^{27}$ Charlotte Johnson, Report on Schools, PRO.

${ }^{28}$ UNESCO, "The Education of Palestine Arab Refugees."

${ }^{29}$ Ibid.

${ }^{30}$ Charlotte Johnson, Report on Schools, PRO.

${ }^{31}$ See for example: Letter from Jaime Torres Bodet, UNESCO Director-General, to Ministry of External Affairs in Colombo, November 18, 1949, ED 157/366, PRO.

32 UNESCO, "The Education of Palestine Arab Refugees."

33 UNRWA, Palestine Refugees Today, Institute for Palestine Studies [IPS] library, Beirut, Lebanon.

${ }^{34}$ Feldman, "Difficult Distinctions," 135.

${ }^{35}$ UNGA Resolution 302(IV), A/RES/302(IV), December 8, 1949, accessed January 20, 2017, https://unispal.un.org/DPA/DPR/unispal.nsf/0/AF5F909791DE7FB0852560E500687282

36 "Double-Shifting in UNRWA/UNESCO Schools: A Study Made by the Research Section at the Institute of Education," 1973, File RE230 Part VI, Box RE 19, UHA.

${ }^{37}$ George Dickerson, "Education for the Palestine Refugees: the UNRWA/UNESCO Programme," Journal of Palestine Studies 3:3 (Spring 1974), 123.

${ }^{38}$ Ibid., 124.

${ }^{39}$ Tom Segev, One Palestine Complete: Jews and Arabs under the British Mandate (London: Abacus, 2001), 514.

${ }^{40}$ Khalidi, Palestinian Identity, 194.

${ }^{41}$ Address by R.H. Ardill, Director of UNRWA/UNESCO Department of Education, at the Third Regional Conferences of Ministers of Education in the Arab States, January 12-20, 1970, File OR230(1-3) II, Box OR 71, UHA.

42 UNESCO, "The Education of Palestine Arab Refugees."

${ }^{43}$ Ibrahim Abu Lughod, "Educating a Community in Exile: The Palestinian Experience," Journal of Palestine Studies 2:3 (Spring 1973): 111.

${ }^{44}$ UNRWA, "The Needs of UNRWA in the Fields of Education and Training," February 10, 1967, File RE230 V, Box RE 19, UHA.

${ }^{45}$ Memo from J.E. Robbins, Chief of UNRWA Education Division, to John Blandford, UNRWA Director, March 24, 1952, Ref 12. 10/C/103, ED 157/366, PRO.

${ }^{46}$ UNESCO, "The Education of Palestine Arab Refugees."

${ }^{47}$ See for instance: Press Statement by Howard Kennedy, UNRWA Director, PAL/565, June 15, 1950, FO 1018/73, PRO. See also: UNRWA, Palestine Refugees Today.

${ }^{48}$ For example: UNRWA, "General Information on UNRWA, its programmes and financial needs," 1977, FCO 93/1304 B, PRO.

${ }^{49}$ UNRWA Annual Reports, accessed January 13, 2017, https://www.unrwa.org/tags/annual-report

${ }^{50}$ Rosenfeld, "From Emergency Relief Assistance to Human Development and Back," 290.

${ }^{51}$ Schiff, Refugees unto the Third Generation, 16-21.

52 Al Husseini, "UNRWA and the Refugees," 8. See also: Lord Macdonald, Speech in the Ad hoc Political Committee, November 29, 1950, FO1018/73, PRO.

${ }^{53}$ Susan Akram, "Palestinian refugees and Their Legal Status: Rights, Politics, and Implications for a Just Solution," Journal of Palestine Studies 31:3 (Spring 2002): 36.

${ }^{54}$ Letter from UK Foreign Office to Ministry of Education, USE 1748/2, August 27, 1952, ED 157/366, PRO.

${ }^{55}$ UNGA Resolution 513, A/RES/513(VI), January 26, 1952, accessed January 20, 2017, https://documents-ddsny.un.org/doc/RESOLUTION/GEN/NR0/067/68/IMG/NR006768.pdf?OpenElement

${ }^{56}$ Soon after UNRWA's creation, Director Howard Kennedy stated, "It must be realised that our Agency has no mandate to deal with the political settlement of the problem." Press Statement by Howard Kennedy, June 15, 1950, FO 1018/73, PRO. 
${ }^{57}$ Extract from a report submitted to the Director General by Dr Matta Akrawi, May 12, 1952, ED 157/366, PRO.

58 Ibid.

${ }^{59}$ UNRWA Public Information Office, Press Review 62/70, July 11, 1970, File RE230(J) III, Box RE 20, UHA.

${ }^{60}$ See for example: Memo from W. van Vliet, Director of UNRWA Education, to Acting CommissionerGeneral, December 9, 1964, File RE230(G) I, Box RE 19; A. Reddaway, Acting Commissioner-General, to L. Fernig, UNESCO Director, October 13, 1967, File OR230(1-3) III, Box OR 71; Memo from M. Beroudiaux, Director of UNRWA Affairs in Lebanon, June 17, 1970, File RE230(L-1) II, Box RE 20 ; S. Samady, UNRWA Director of Education, Speech to Seventh National Development Conference in Beirut, November 24-25, 1973, File RE230 VI, Box RE 19, all in UHA. See also: John Reddaway, "UNRWA: a second look at the record - were the critics mistaken?," The New Middle East 16 (January 1970): 25.

${ }^{61}$ Dickerson, "Education for the Palestine Refugees: the UNRWA/UNESCO Programme," 128.

${ }^{62}$ Abu Lughod, "Educating a Community in Exile: The Palestinian Experience," 96-97.

${ }^{63}$ Dickerson, "Education for the Palestine Refugees: the UNRWA/UNESCO Programme," 128-129.

${ }^{64}$ UNRWA Public Information Office Press Review No. 62/70, July 11, 1970, File RE230(J) III, Box RE 20, UHA. Reddaway, "UNRWA: a second look at the record - were the critics mistaken?," 25.

${ }^{65}$ Resolutions of the Conference of Arab Ministers of Education, Kuwait, February 1968, File RE 230(5) I, Box RE 28, UHA.

${ }^{66}$ Milton Viorst, UNRW A and Peace in the Middle East (Washington DC: Middle East Institute, 1984), 30 34.

${ }^{67}$ UNRWA, Palestine Refugees Today, 65, December 1970, IPS.

${ }^{68}$ See for example: Declaration from Palestinian Pupils in Lebanon, L/510, n.d., Inactive Files, Box 7; Statement by Badge of the Arab Palestine Youth in Lebanon, January 1, 1960, File RE-150 I, Box RE3; "The Palestinians in Lebanon" statement "We are returning," November 29, 1962, File RE 150 1, Box RE 3 , all in UHA.

${ }^{69}$ Letter from the Committee of Action for the Congress of the Palestinian Refugees to the Soviet government, November 29, 1950, FO1018/73, PRO.

70 Turki, The Disinherited, 36.

${ }^{71}$ Y. Sayigh, Armed Struggle and the Search for State, 47.

72 R. Sayigh, Too Many Enemies, 53.

73 Ibid., 54-55.

${ }^{74}$ Abu Lughod, "Educating a Community in Exile: The Palestinian Experience," 103.

75 Y. Sayigh, Armed Struggle and the Search for State, 47.

${ }^{76}$ Ilana Feldman, Governing Gaza. Bureaucracy, Authority and the Work of Rule, 1917-67 (London: Duke University Press, 2008), 129.

${ }^{77}$ Fawaz Turki, Soul in Exile: Lives of a Palestinian Revolutionary (New York: Monthly Review Press, 1988), 55.

${ }^{78}$ Leila Khaled and George Hajjar, My People Shall Live: The Autobiography of a Revolutionary (London:

Hodder and Stoughton, 1973), 28-36. Fawaz Turki, Exile's Return: The Making of a Palestinian

American. New York: Free Press, 1994), 56-57.

${ }^{79}$ Report of the Working Party convened by UNESCO to make recommendations on the possible development of the UNRWA-UNESCO Education Programme for Palestine Refugees in the Near East, April 28-30, 1952, ED 157/366, PRO.

${ }^{80}$ Schiff, Refugees Unto the Third Generation, 21.

${ }^{81}$ Lex Takkenberg, "UNRWA and the Palestinian Refugees After Sixty Years: Some Reflections," Refugee Survey Quarterly 28:2-3 (2010): 255.

82 Forsythe, "The Palestine Question: Dealing with a Long-Term Refugee Situation," 92.

${ }^{83}$ Memo from J. Robbins to Blandford, March 24, 1952; UNESCO, "Schools for Arab Refugees," May 19, 1952, both in ED 157/366, PRO.

${ }^{84}$ Schiff, Refugees Unto the Third Generation, 28. Al Husseini, "UNRWA and the Refugees," 13.

${ }^{85}$ Rosenfeld, "From Emergency Relief Assistance to Human Development and Back," 289-300.

86 See: "Recommendations of the Conference of Arab host states and UNRWA/UNESCO on the Educational Curriculum for Children of Palestine Arab refugees," March 5-8, 1969, No File, Box OR 70; Memo from R.H. Ardill, Director of Education, to Director of UNRWA Affairs in Lebanon, March 22, 1969, ED/110, File RE230(L-1) II, Box RE 20; UNRWA Cabinet Memorandum 35/69, "New Training Activities Proposed to be taken by the UNRWA/UNESCO Institute of Education," November 26, 1969 , File RE230(L-1) IV, Box RE 21; Laurence Michelmore, Comments on Appeal from Secretary-General of the Federation of Arab Teachers, June 5, 1970, File RE 230(1) S, Box RE 27, all in UHA.

${ }^{87}$ Interview with Hasna Rida, former UNRWA Education Researcher, Beirut, December 7, 2016.

88 Shabaneh, "Education and Identity," 492-500. 
${ }^{89}$ Rosemary Sayigh, The Palestinians: From Peasants to Revolutionaries (London: Zed Books, 2007), 112. 